\title{
The Nucleotide-Binding Domain and Leucine-Rich Repeat Protein-3 Inflammasome Is Not Activated in Airway Smooth Muscle Upon Toll-Like Receptor-2 Ligation
}

\author{
Jeremy A. Hirota1*, Hanna Im²*, Mostafizur M. Rahman², Nowshin N. Rumzhum², Melanie Manetsch², \\ Chris D. Pascoe ${ }^{1}$, Kristin Bunge ${ }^{2}$, Hatem Alkhouri², Brian G. Oliver ${ }^{3}$, and Alaina J. Ammit ${ }^{2}$ \\ ${ }^{1}$ University of British Columbia James Hogg Research Centre Heart and Lung Institute, St. Paul's Hospital, Vancouver, British Columbia, Canada; and \\ ${ }^{2}$ Respiratory Research Group, Faculty of Pharmacy, and ${ }^{3}$ Woolcock Institute of Medical Research, University of Sydney, New South Wales, Australia
}

\begin{abstract}
Inflammasomes have emerged as playing key roles in inflammation and innate immunity. A growing body of evidence has suggested that the nucleotide-binding domain and leucine-rich repeat protein-3 (NLRP3) inflammasome is important in chronic airway diseases such as asthma and chronic obstructive pulmonary disease. Inflammasome activation results, in part, in pro-IL-1 $\beta$ processing and the secretion

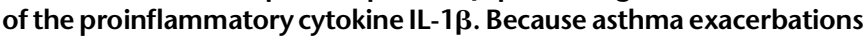
are associated with elevated concentrations of secreted IL-1及, we addressed whether the NLRP3 inflammasome is activated under in vitro conditions that mimic infectious exacerbations in asthma. Primary cultures of airway smooth muscle (ASM) cells were treated with infectious stimuli (mimicked using the Toll-like receptor-2 agonist Pam3CSK4, a synthetic bacterial lipopeptide). Whereas Pam3CSK4 robustly up-regulated ASM cytokine expression in response to TNF- $\alpha$ and significantly enhanced IL-1ß mRNA expression, we were unable to

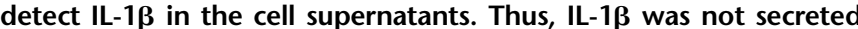
and therefore was unable to act in an autocrine manner to promote the amplification of ASM inflammatory responses. Moreover, Toll-like receptor-2 ligation did not enhance NLRP3 or caspase-1 expression in ASM cells, and NLRP3 and caspase-1 protein were not present in the ASM layer of tracheal sections from human donors. In conclusion, these data demonstrate that the enhanced synthetic function of ASM cells, induced by infectious exacerbations of airway inflamma-

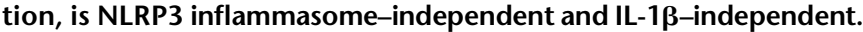
Activation of the NLRP3 inflammasome by invading pathogens may prove cell type-specific in exacerbations of airway inflammation in asthma.
\end{abstract}

Keywords: interleukin-1 $\beta$; NLRP3; caspase-1; inflammasome; TLR2

Inflammasomes control innate immunity and inflammation. By regulating the processing and release of proinflammatory cytokines (predominantly IL-1 $\beta$ ), burgeoning evidence supports a key role

(Received in original form January 29, 2013 and in final form April 10, 2013)

*These authors contributed equally to this work.

J.A.H. is a recipient of Canadian Institutes of Health Research, Integrated and Mentored Pulmonary and Cardiovascular Training strategic training, the Michae Smith Foundation for Health Research, and AllerGen NCE postdoctoral training fellowships. Doctoral students were supported by an Endeavour Postgraduate Award (M.M.R.), an International Postgraduate Research Scholarship (N.N.R.), and the Senglet Stiftung (Switzerland) (M.M.). A.J.A. was funded by project grants from the National Health and Medical Research Council of Australia.

Correspondence and requests for reprints should be addressed to Alaina J. Ammit, Ph.D., Respiratory Research Group, Faculty of Pharmacy, Building A15 Room S222, University of Sydney, New South Wales 2006, Australia. E-mail: alaina.ammit@sydney.edu.au

This article has an online supplement, which is accessible from this issue's table of contents at www.atsjournals.org

Am J Respir Cell Mol Biol Vol 49, Iss. 4, pp 517-524, Oct 2013

Copyright $\odot 2013$ by the American Thoracic Society

Originally Published in Press as DOI: 10.1165/rcmb.2013-00470C on May 13, 2013

Internet address: www.atsjournals.org for inflammasome activation in lung diseases such as asthma and chronic obstructive pulmonary disease, as recently reviewed (1, $2)$. The nucleotide-binding domain and leucine-rich repeat protein-3 (NLRP3) inflammasome has been best characterized, and both in vivo and in vitro models of allergic asthma and asthmatic inflammation have demonstrated an important role for the NLRP3 inflammasome in the amplification and potentiation of inflammation during airway disease (3-5). Because elevated IL-1 $\beta$ protein secretion was suggested to play a role in asthma exacerbation (5, 6 ), we were interested in exploring whether the NLRP3 inflammasome is activated under in vitro conditions that mimic infectious exacerbations in asthma

The NLRP3 inflammasome is a multimeric intracellular protein complex consisting of three domains: NLRP3, the apoptosisassociated speck-like protein containing the caspase activation and recruitment domain, and caspase-1 (7). The sensor protein NLRP3 regulates inflammasome assembly in a temporal and spatial manner (8). NLRP3 expression is inducible, and mRNA regulation can take place at the transcriptional and posttranscriptional levels $(9,10)$. Recognition of invading pathogens by the NLRP3 domain results in the assembly of three components to form a stable inflammasome, which in turn activates pro-caspase-1 into active caspase- 1 autocatalytically (1). Caspase- 1 is a cysteine protease that cleaves inactive precursors of IL-1 $\beta$ into bioactive cytokine, which is then competent to be secreted out of the cell.

During the past decade, the ability of airway smooth muscle (ASM) cells to produce and secrete proinflammatory mediators, including cytokines and chemokines, has been established by many studies, as reviewed elsewhere $(11,12)$. Furthermore, accumulating evidence has shown that the treatment of ASM cells with IL-1 $\beta$ in vitro augments the production of numerous proinflammatory mediators, including IL-6, IL-8 (13), IL-17A (14), prostaglandin $\mathrm{E}_{2}(15)$, and matrix metalloproteinase-9 (16), thus serving to amplify airway inflammation. The enhanced synthetic function of ASM may play a pivotal role, leading to acute exacerbations of asthma, by provoking and amplifying airway inflammatory responses $(17,18)$. To date, however, most NLRP3 inflammasome studies have been limited to airway epithelium and macrophages (19). The possible involvement of the NLRP3 inflammasome and IL-1 $\beta$ activation in the enhanced synthetic function of ASM cells in response to invading pathogens remains largely unexplored.

Intriguingly, our previous studies revealed an important celltype difference in human airways. Whereas NLRP3 and caspase-1 were present in human lung epithelium, as shown by Hirota and colleagues (19) and confirmed here, these proteins were not present in dissected ASM strips, and neither were they detected by immunohistochemistry in human tracheal sections. These in situ data support our in vitro studies, where the engagement of Toll-like receptor 2 (TLR2) with the TLR2 agonist Pam3CSK4 exerted no effect on NLRP3 and caspase-1 expression. These 
TABLE 1. SUBJECT CHARACTERISTICS

\begin{tabular}{|c|c|c|c|c|c|c|}
\hline Immunohistochemistry Samples & Age $(y r)$ & Sex & Status & Weight $(\mathrm{kg})$ & Height $(\mathrm{cm})$ & Cause of Death \\
\hline Donor 1 & 19 & $\mathrm{~F}$ & Not asthmatic & 87 & 165 & Head trauma, MVA \\
\hline Donor 2 & 20 & $\mathrm{~F}$ & Not asthmatic & 72.2 & 165 & Head trauma \\
\hline Donor 3 & 25 & M & Asthmatic & 103 & 185 & Anoxia \\
\hline \multicolumn{7}{|l|}{ Immunoblot Samples } \\
\hline Donor 4 & 11 & M & Not asthmatic & 49.9 & 157 & CVA \\
\hline Donor 5 & 26 & $\mathrm{~F}$ & Asthmatic & 91.6 & 168 & Anoxia, probable asthma attack \\
\hline Donor 6 & 20 & $\mathrm{M}$ & Asthmatic & 81.2 & 172.7 & Head trauma \\
\hline
\end{tabular}

Definition of abbreviations: CVA, cardiovascular attack; MVA, motor vehicle accident.

results suggest that because of the absence of these key components, NLRP3 inflammasome activation will not be possible, and consequently IL-1 $\beta$ will not be processed for secretion. Our data support this assertion, because we show that although TLR2 ligation increased TNF- $\alpha$-induced IL- $1 \beta$ mRNA expression, IL-1 $\beta$ is not secreted from ASM cells. Thus, the NLRP3 inflammasome is not activated in ASM upon TLR2 ligation.

\section{MATERIALS AND METHODS}

\section{Human ASM Cell Culture}

Human bronchi were obtained from patients undergoing surgical resection for carcinoma or from lung transplant donors, in accordance with procedures approved by the Sydney South West Area Health Service and the Human Research Ethics Committee at the University of Sydney. A minimum of three different ASM primary cell cultures established from individual patients was used for each experiment, in accordance with established procedures (20). Unless otherwise specified, all chemicals used in this study were purchased from SigmaAldrich (St. Louis, MO).

\section{Real-Time RT-PCR}

Total RNA was extracted using the RNeasy Mini Kit (Qiagen, Doncaster, Victoria, Australia), and reverse-transcribed using the RevertAid First Strand cDNA Synthesis Kit (Fermentas Life Sciences, Hanover, MD). Real-time RT-PCR was performed on an ABI Prism 7500 (Applied Biosystems, Foster City, CA) with IL-1 $\beta$ (TaqMan ID: Hs01555410_m1), IL-6 (Hs00174131_m1), IL-8 (Hs00174103_m1), NLRP3 (Hs00918082_m1), and $18 \mathrm{~S}$ ribosomal RNA measured with TaqMan probes (Applied Biosystems)

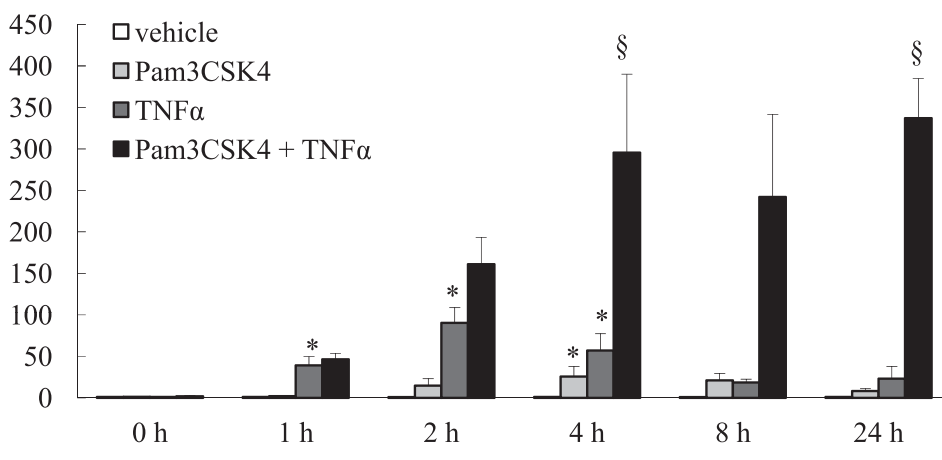

B

$$
\begin{array}{r}
160 \\
140 \\
120 \\
100 \\
80 \\
60 \\
40 \\
20 \\
0
\end{array}
$$

口vehicle

$120-\square \mathrm{TNF} \alpha$

- Pam3CSK4 + TNF $\alpha$<smiles></smiles>

$24 \mathrm{~h}$

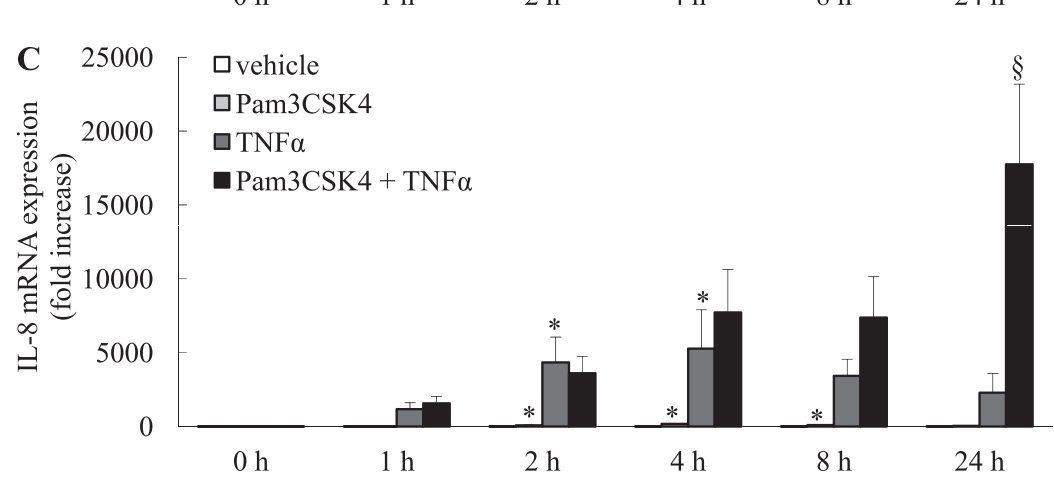

Figure 1. Time course of TNF- $\alpha$-induced IL-1 $\beta$ mRNA expression and augmentation by Pam3CSK4 (in comparison with IL-6 and IL-8 mRNA temporal kinetics). Growtharrested airway smooth muscle (ASM) cells were pretreated with vehicle or Pam3CSK4 $(1 \mu \mathrm{g} / \mathrm{ml}$ ) for 1 hour, followed by treatment with vehicle or TNF- $\alpha(10 \mathrm{ng} / \mathrm{ml})$ for $0,1,2,4,8$, and 24 hours. (A) IL-1 $\beta,(B) \mathrm{IL}-6$, and (C) IL-8 mRNA expression was quantified by real-time RT-PCR, and the results are expressed as fold increase compared with vehicle-treated cells at 0 hour (mean \pm SEM values from $n=7$ primary ASM cell cultures). Statistical analysis was performed using two-way ANOVA, and then the Bonferroni post hoc test (where an asterisk denotes a significant effect of treatment on mRNA expression, compared with vehicle-treated cells; ${ }^{\S}$ significant effect of Pam3CSK4 on TNF- $\alpha$-induced mRNA expression at the same time point; $P<0.05)$. h, hours. 
or caspase-1 (PPH00105B) and 18S (PPH0566E) measured by SYBR Green $\mathrm{RT}^{2}$ qPCR Primer Assays (Qiagen).

\section{ELISAs}

IL-1 $\beta$ (DuoSet DY201; R\&D Systems, Minneapolis, MN), IL-6 (BD OptEIA 555220; BD Biosciences, San Diego, CA), and IL-8 (BD OptEIA 555244; BD Biosciences) ELISAs were performed according to the manufacturers' instructions.

\section{IL-1及 Neutralization}

To neutralize IL-1 $\beta$, conditioned media from treated ASM cells or IL-1 $\beta$ recombinant protein (R\&D Systems) were incubated for 1 hour at $37^{\circ} \mathrm{C}$ with $2 \mu \mathrm{g} / \mathrm{ml}$ of either vehicle, normal mouse $\operatorname{IgG}_{1}$ (Santa Cruz Biotechnology, Santa Cruz, CA) as an isotype control, or a monoclonal mouse $\mathrm{IgG}_{1}$ antibody to human recombinant IL-1 $\beta$ (clone 8516 ; R\&D Systems).

\section{Immunoblotting of ASM Cell Lysates}

NLRP3 or caspase-1 in ASM cells was detected by immunoblotting with rabbit anti-human NLRP3 (HPA012878; Sigma-Aldrich) or caspase-1 polyclonal antibodies (catalogue number 2225; Cell Signaling Technology, Danvers, MA), compared with $\alpha$-tubulin as the loading control (mouse monoclonal $\mathrm{IgG}_{1}$, DM1A; Santa Cruz Biotechnology). Primary antibodies were detected with goat anti-mouse or anti-rabbit horseradish peroxidase-conjugated secondary antibodies (Cell Signaling Technology), and visualized by enhanced chemiluminescence (PerkinElmer, Wellesley, MA). Lysates from THP-1 monocyte cells treated with and without phorbol myristate acetate $(50 \mathrm{ng} / \mathrm{ml})$ served as positive controls (19).

\section{Human Lung Tissue}

Human tracheas were obtained from lungs donated for medical research at the International Institute for the Advancement of Medicine (Edison, NJ) (19). Tracheas from three individual patients were used for each experiment. For the immunohistochemical analysis of NLRP3 and caspase- 1 in human tracheas, tissue was fixed in $10 \%$ formalin and processed for immunohistochemistry (see the online supplement). For the immunoblotting of NLRP3 and caspase-1, tracheas were stored in Krebs solution, and then ASM was isolated and protein was extracted for immunoblotting (see the online supplement). For subject characteristics, please see Table 1.

\section{Statistical Analysis}

Statistical analysis was performed using either the Student unpaired $t$ test or two-way ANOVA, followed by the Bonferroni post hoc test. $P<0.05$ was considered sufficient to reject the null hypothesis for all analyses. Data represent means \pm SEMs.

\section{RESULTS}

Time Course of TNF- $\alpha$-Induced IL-1 $\beta$ mRNA Expression and Augmentation by Pam3CSK4

We measured the temporal kinetics of TNF- $\alpha$-induced IL-1 $\beta$ mRNA expression in ASM cells, and examined whether the TLR2 agonist, Pam3CSK4, up-regulated IL-1 $\beta$ concentrations. As shown in Figure 1A, TNF- $\alpha$ significantly enhanced IL-1 $\beta$ mRNA expression over time, with significant expression observed
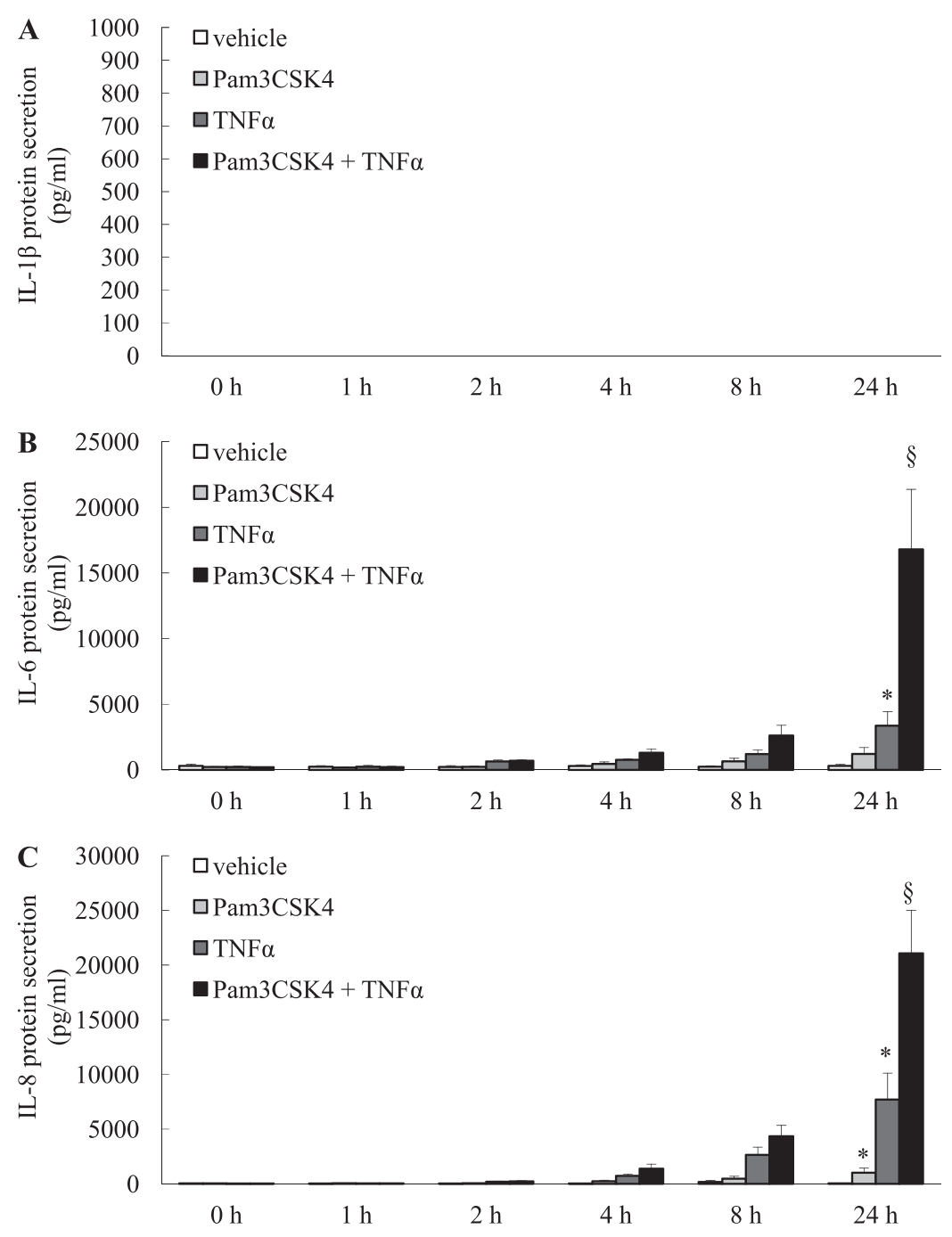

Figure 2. Pam 3 CSK 4 potentiates TNF- $\alpha$-induced IL- 6 and IL-8 protein secretion, but IL- $1 \beta$ is not secreted from ASM cells. Growth-arrested ASM cells were pretreated with vehicle or Pam3CSK4 $(1 \mu \mathrm{g} / \mathrm{ml})$ for 1 hour, followed by treatment with vehicle or TNF- $\alpha(10 \mathrm{ng} / \mathrm{ml})$ for $0,1,2$, 4,8 , and 24 hours. ELISAs were used to measure $(A)$ IL-1 $\beta$, (B) IL-8, and (C) IL-6 protein secretion. Note that IL-1 $\beta$ secretion from ASM cells $(A)$ was not detected. Statistical analysis was performed using two-way ANOVA and then the Bonferroni post hoc test (where an asterisk denotes a significant effect of treatment on protein secretion, compared with vehicle-treated cells; §significant effect of Pam 3CSK4 on TNF- $\alpha$-induced protein secretion at the same time point; $P<0.05$ ). Data represent the mean \pm SEM values from $n=4$ primary ASM cell cultures. 
as early as 1 hour, and a peak of 90.4- \pm 18.4-fold at 2 hours, before subsiding to concentrations that were not significantly different from those of vehicle controls by 8 hours $(P<0.05)$. Pam3CSK4 alone also significantly enhanced IL-1 $\beta$ mRNA expression, with a significant $14.8- \pm 8$.4-fold increase observed at 4 hours $(P<0.05)$. Importantly, TNF- $\alpha$-induced IL-1 $\beta$ upregulation was significantly potentiated by Pam3CSK $4(P<$ 0.05). As shown in Figure 1A, the effect of Pam3CSK4 on TNF- $\alpha$-induced IL-1 $\beta$ mRNA was first observed at 2 hours (although not significantly), and this effect increased to significant levels at 4 hours, and by 24 hours was measured at 337.0- \pm 48.0-fold, compared with 23.0- \pm 14.9-fold using TNF- $\alpha$ alone $(P<0.05)$.

Interestingly, when we compared the temporal kinetics of IL-1 $\beta$ mRNA expression with those of IL-6 (Figure 1B) and IL-8 (Figure 1C), we also observed a later significant up-regulation of TNF- $\alpha$-induced cytokine secretion at 24 hours $(P<0.05)$. This raises the intriguing possibility that the early phase of IL-1 $\beta$ mRNA may undergo translation, to result in IL-1 $\beta$ protein secretion that can then act back on ASM cells in an autocrine manner to stimulate the cytokine mRNA expression observed at 24 hours. Thus, we hypothesize that the TLR2 agonist, Pam3CSK4, activates the inflammasome to result in IL-1 $\beta$ secretion from ASM cells and the potentiation of cytokine secretion from ASM cells.

\section{Pam3CSK4 Potentiates TNF- $\alpha-$ Induced IL- 6 and IL-8 Protein Secretion, but IL-1及 Is Not Secreted from ASM cells}

To address this hypothesis, we measured concentrations of IL$1 \beta$, IL-6, and IL-8, as secreted from ASM cells over 0 to 24 hours. As shown in Figures 2B and 2C, respectively, Pam3CSK4 pretreatment significantly enhanced TNF- $\alpha$-induced IL- 6 and IL-8 at 24 hours (Figures $2 \mathrm{~A}$ and $2 \mathrm{~B} ; P<0.05$ ), in confirmation of our earlier report (18). We then attempted to measure IL-1 $\beta$ in the same supernatants, using an ELISA that had been confirmed able to measure secreted IL- $1 \beta$ that resulted from inflammasome activation (21). Importantly, IL-1 $\beta$ was not detected (Figure 2A), suggesting that even though IL-1 $\beta$ mRNA was up-regulated, the inflammasome was not activated and IL-1 $\beta$ was not secreted from ASM cells.

\section{Neutralization of IL-1ß in Conditioned Media Exerts No Effect on Cytokine Secretion}

To confirm that IL-1 $\beta$ was not secreted from ASM cells, we used an IL-1 $\beta$-neutralizing antibody. We initially validated IL-1 $\beta$ neutralization by incubating a range of concentrations of IL$1 \beta$ recombinant protein $(1-500 \mathrm{pg} / \mathrm{ml})$ with $\mathrm{IL}-1 \beta-$-neutralizing antibody, and measured its inhibitory effect on IL-1 $\beta$-induced IL-6 and IL-8 protein secretion. As shown in Figure 3, IL-1 $\beta$ induced a concentration-dependent augmentation of IL- 6 and IL-8 protein secretion in vehicle-treated or isotype control-treated ASM cells, with no significant difference between cells treated with vehicle or the isotype control. Importantly, the neutralization of IL- $1 \beta$ reduced IL- 6 protein secretion from ASM cells in response to a range of IL- $1 \beta$ concentrations $(1-500 \mathrm{pg} / \mathrm{ml}$; Figure 3A), with only $79.5 \pm 39.8 \mathrm{pg} / \mathrm{ml}$ IL-6 secreted in response to $500 \mathrm{ng} / \mathrm{ml}$ IL-1 $\beta$ preincubated with the IL-1 $\beta$ neutralizing antibody, as opposed to approximately 150 -fold greater amounts of IL-6 secretion after preincubation with the isotype control $(P<0.05)$. Similarly, this down-regulation by IL-1 $\beta$ neutralization was also observed in IL-8 protein secretion, as depicted in Figure 3B.

We next examined whether the neutralization of IL-1 $\beta$ in conditioned media exerted any effect on IL- 6 and IL- 8 protein secretion by ASM cells. As shown in Figure 4A, the removal of IL-1 $\beta$ by the neutralizing antibody exerted no effect on the amount of IL- 6 secreted in response to conditioned media from cells stimulated with TNF- $\alpha$ alone or Pam3CSK $4+$ TNF- $\alpha$. Similarly, IL-8 secretion in response to conditioned media preincubated with IL-1 $\beta$-neutralizing antibody was not significantly different from that preincubated with the isotype control (Figure $4 B)$. As a positive control, we confirmed IL-1 $\beta$ neutralization
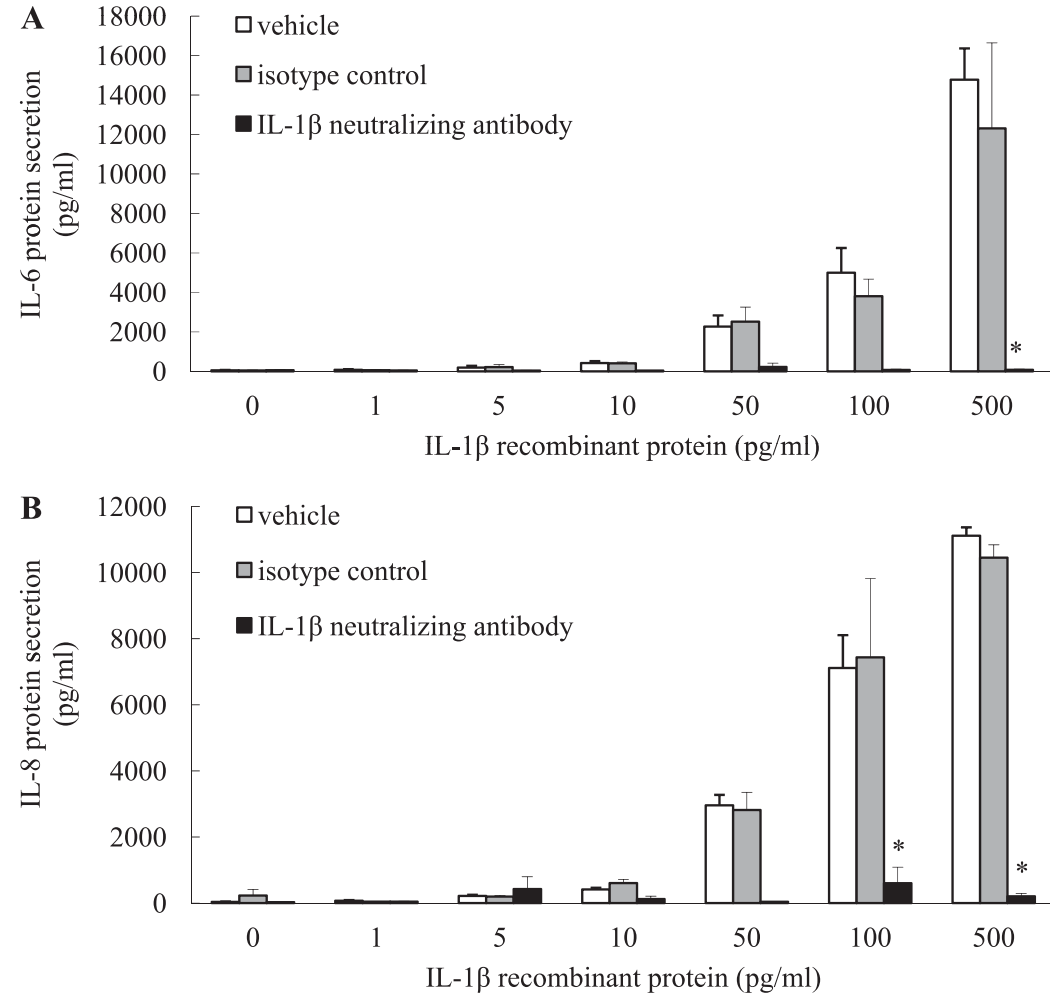

Figure 3. Effect of IL-1 $\beta$-neutralizing antibody on IL-6 and IL- 8 protein secretion induced by IL- $1 \beta$ recombinant protein. To validate the effect of neutralization antibody on IL-6 $(A)$ and IL-8 $(B)$ protein secretion, vehicle or increasing concentrations of IL-1 $\beta$ recombinant protein $(1-500 \mathrm{pg} /$ $\mathrm{ml}$ ) were incubated for 1 hour at $37^{\circ} \mathrm{C}$ with $2 \mu \mathrm{g} / \mathrm{ml}$ of vehicle, isotype control, or IL-1 $\beta$-neutralizing antibody, and then added to growth-arrested ASM cells for 24 hours. IL- 6 and IL-8 protein secretion was measured by ELISA. Statistical analysis was performed using two-way ANOVA and then the Bonferroni post hoc test (where an asterisk denotes a significant effect of IL-1 $\beta$-neutralizing antibody on protein secretion, compared with the isotype control; $P<0.05)$. Data represent the mean \pm SEM values from $n=3$ primary ASM cell cultures. 


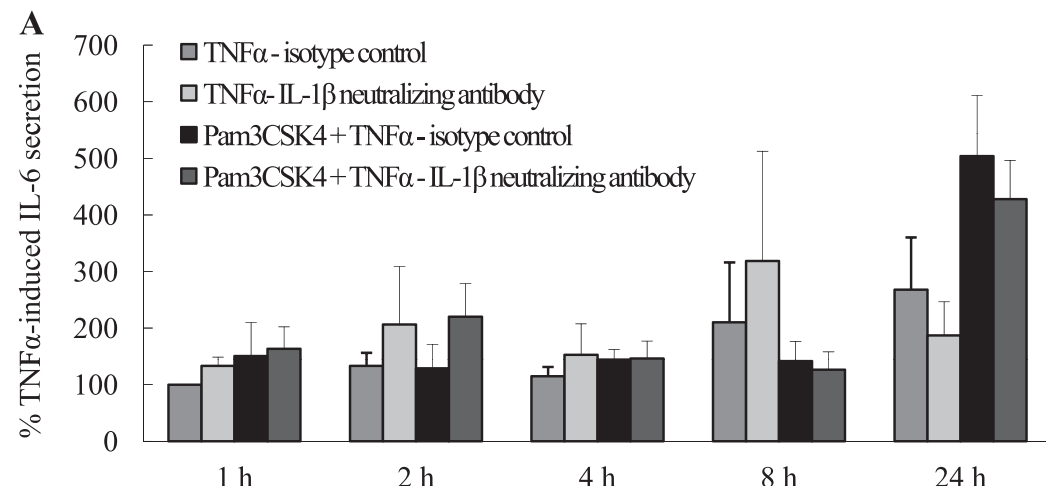

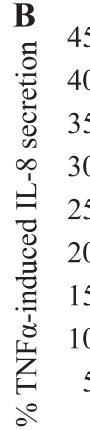
$450 \quad \square \mathrm{TNF} \alpha$-isotype control
$400-\square \mathrm{TNF} \alpha-\mathrm{IL}-1 \beta$ neutralizing antibody
350 - $\square$ Pam3CSK4+TNF $\alpha$-isotype control
$300-\square$ Pam3CSK4+TNF $\alpha-I L-1 \beta$ neutralizing antibody

250

200

150

100

50

(

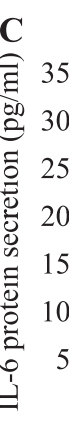

1

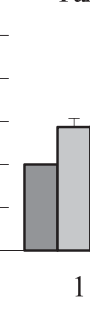

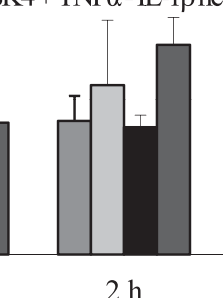

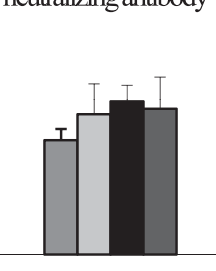

$4 \mathrm{~h}$

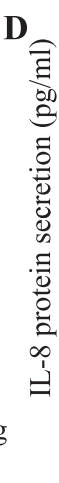

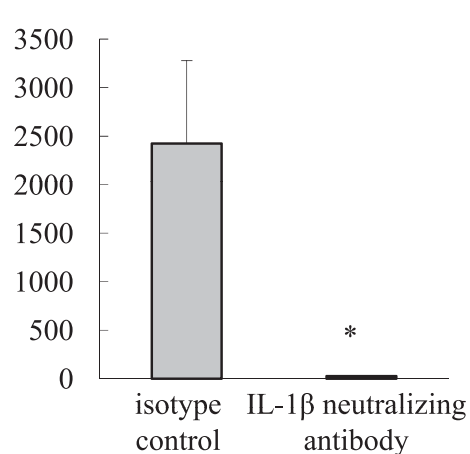

Figure 4. The neutralization of IL-1 $\beta$ in conditioned media exerts no effect on cytokine secretion. Conditioned media were prepared by removing supernatants from ASM cells treated with TNF- $\alpha$ or Pam3CSK4 + TNF- $\alpha$ for 1, 2, 4, 8, and 24 hours. Conditioned media were incubated at $37^{\circ} \mathrm{C}$ for 1 hour with $2 \mu \mathrm{g} / \mathrm{ml}$ of either IL-1 $\beta$-neutralizing antibody or isotype control, and then incubated with ASM cells for 24 hours. The resultant (A) IL-6 and (B) IL-8 protein in the supernatants was measured by ELISA. Results were expressed as a percentage of TNF- $\alpha$-induced cytokine in isotype control at 1 hour. To confirm IL-1 $\beta$ neutralization, parallel experiments were conducted with vehicle or IL-1 $\beta$ recombinant protein $(100 \mathrm{pg} / \mathrm{ml})$ treated under identical conditions, and (C) IL- 6 and $(D)$ IL- 8 were measured by ELISA. Statistical analysis was performed using the Student unpaired $t$ test (where an asterisk denotes a significant effect of IL-1 $\beta$-neutralizing antibody on protein secretion, compared with isotype control). Data represent mean \pm SEM values from $n=3$ primary ASM cell cultures. with ASM cells treated with $100 \mathrm{ng} / \mathrm{ml}$ IL-1 $\beta$ recombinant protein in parallel experiments. As shown in Figures 4C and 4D, IL$1 \beta$ neutralization significantly inhibited IL-6 and IL-8 secretion from ASM cells, compared with the isotype control $(P<0.05)$.

\section{Pam3CSK4 Does Not Affect TNF- $\alpha$-Induced NLRP3 mRNA and Protein Expression in ASM Cells}

NLRP3 is an important component of the inflammasome, and has been shown to be up-regulated under inflammatory conditions. Caspase- 1 also plays an important role in inflammasome function, to cleave precursor pro-IL- $1 \beta$ into mature IL-1 $\beta$. Collectively, our data thus far demonstrate that the Pam3CSK4mediated augmentation of TNF- $\alpha$-induced IL- 6 and IL- 8 mRNA and protein concentrations is not mediated by IL-1 $\beta$ secretion. Thus, these results indicate that components of the NLRP3 inflammasome may not be up-regulated in ASM cells upon TLR2 activation. To address this, we measured NLRP3 and caspase- 1 mRNA expression in response to Pam3CSK4 and TNF- $\alpha$, alone and in combination, over time (0-24 h). As shown in Figure 5A, neither Pam3CSK4 nor TNF- $\alpha$ exerted a significant effect on NLRP3 mRNA expression over 24 hours. Moreover, the temporal kinetics of NLRP3 mRNA expression was not affected in response to Pam $3 \mathrm{CSK} 4+\mathrm{TNF}-\alpha$ in combination. Importantly, we were unable to detect NLRP3 protein in the lysates of human ASM cells, in confirmation of our mRNA results. As shown in Figure 5C, NLRP3 protein was not detected, or up-regulated, by treatment with Pam3CSK 4 or TNF$\alpha$, alone or in combination. We also measured the temporal kinetics of caspase- 1 mRNA expression in response to Pam3CSK $4+$ TNF- $\alpha$, alone and in combination (Figure 5B). Whereas TNF- $\alpha$ induced a small ( $\sim 3$-fold) but significant effect on caspase-1 mRNA expression at 8 hours $(P<0.05)$, this did not result in changes in caspase- 1 protein (Figure 5D). Importantly, Pam3CSK 4 did not up-regulate TNF- $\alpha$-induced caspase- 1 mRNA and protein expression. Taken together, these results suggest that because NLRP3 and caspase-1 protein are not present in ASM cells, the NLRP3 inflammasome is not activated upon TLR2 ligation. Thus, IL-1 $\beta$ is not secreted from ASM cells.

\section{NLRP3 and Caspase-1 Are Not Expressed in ASM from Human Tracheal Tissue}

We then investigated whether NLRP3 and caspase-1 are present in human tracheas in situ, using immunohistochemistry and immunoblot analyses of protein isolated from ASM strips freshly dissected from human tracheas. As shown via immunohistochemistry, whereas the epithelial layer is positive 

4.5 - $\square$ vehicle
$4.0-\square \mathrm{Pam} 3 \mathrm{CSK} 4$
$3.5-\square \mathrm{TNF} \alpha$
$3.0-\mathrm{Pam} 3 \mathrm{CSK} 4+\mathrm{TNF} \alpha$

2.5

2.0

1.5
1.0

1.0
0.5

0.0
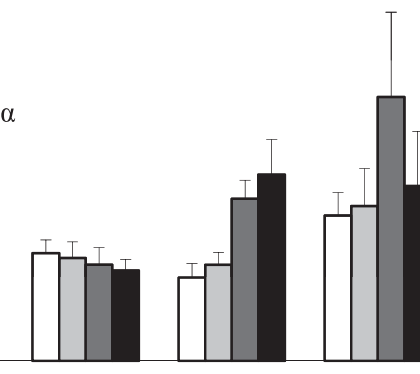

$0 \mathrm{~h}$
$2 \mathrm{~h}$
$4 \mathrm{~h}$

$8 \mathrm{~h}$

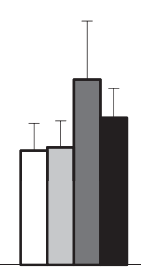

$24 \mathrm{~h}$

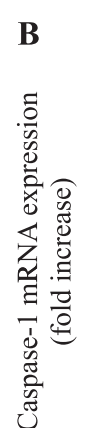

C
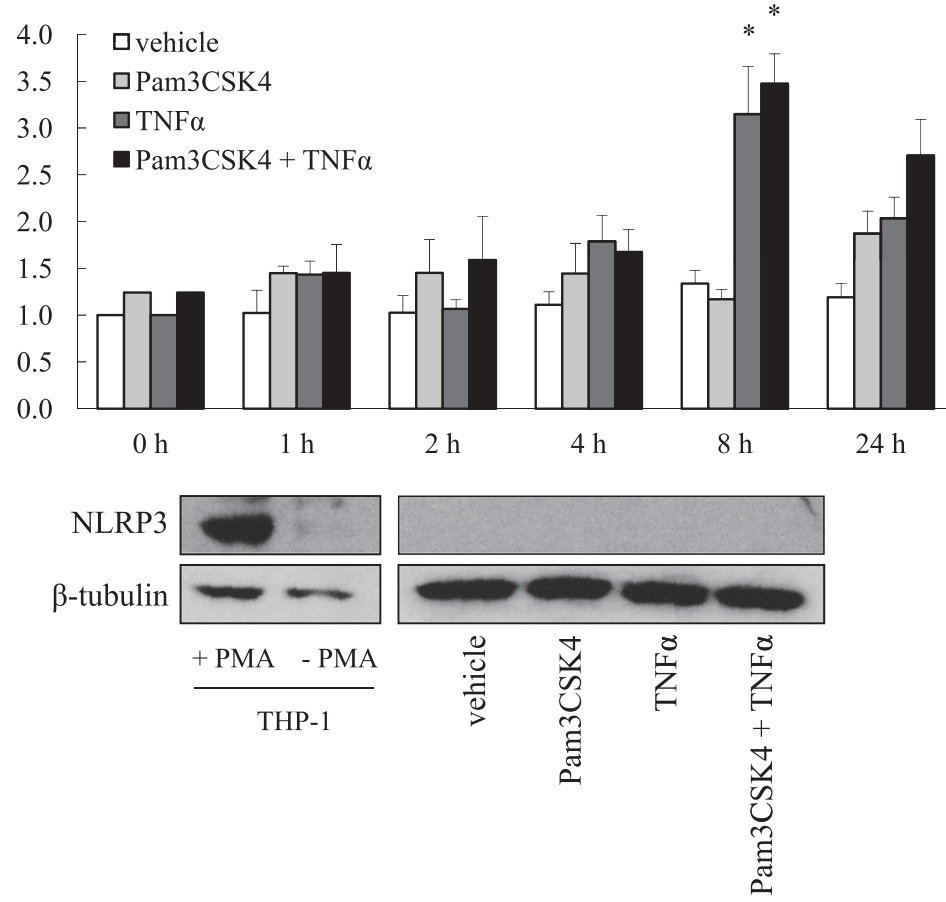

D

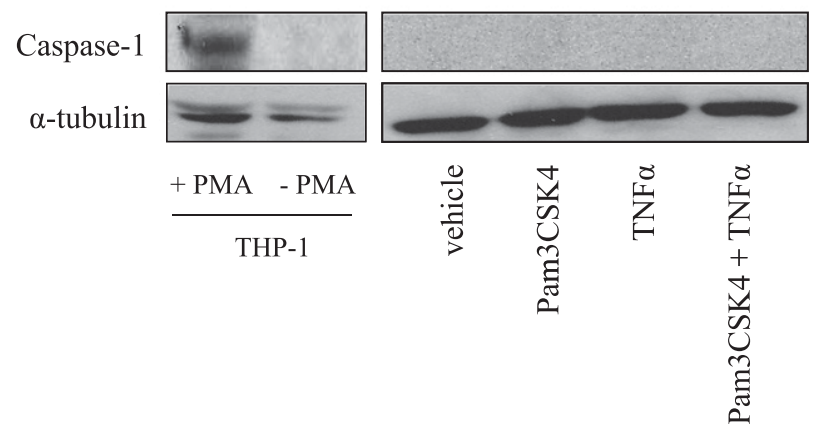

Figure 5. Pam 3 CSK4 does not affect TNF- $\alpha$-induced nucleotide-binding domain and leucine-rich repeat protein-3 (NLRP3) mRNA and protein expression in ASM cells. $(A$ and $B$ ) Growth-arrested ASM cells were pretreated with vehicle or Pam3CSK4 $(1 \mu \mathrm{g} / \mathrm{ml})$ for 1 hour, followed by treatment with vehicle or TNF- $\alpha(10 \mathrm{ng} / \mathrm{ml})$ for $0,1,2$, 4,8 , and 24 hours. (A) NLRP3 and (B) caspase- 1 mRNA expression was quantified by real-time RT-PCR, and results are expressed as fold increase compared with vehicle-treated cells at 0 hour, expressed as mean \pm SEM values from $(A) n=6$ or $(B) n=4$ primary ASM cell cultures. Statistical analysis was performed using twoway ANOVA and then the Bonferroni post hoc test (where an asterisk denotes a significant effect of treatment on caspase-1 mRNA expression, compared with vehicle-treated cells; $P<0.05$ ). ( $C$ and $D$ ) Growth-arrested ASM cells were pretreated with vehicle or Pam3CSK4 $(1 \mu \mathrm{g} / \mathrm{ml})$ for 1 hour, followed by treatment with vehicle or TNF- $\alpha(10 \mathrm{ng} / \mathrm{ml})$ for 24 hours. Whole cell lysates were prepared and immunoblotted for (C) NLRP3 and (D) caspase-1 protein, using $\alpha$-tubulin as the loading control. ( $C$ and $D$ ) Representative blots of $n=3$ primary ASM cell cultures and lysates from THP-1 monocytes, treated with or without phorbol myristate acetate (PMA; $50 \mathrm{ng} / \mathrm{ml}$ ), served as positive controls. for NLRP3 (Figures 6A-6F) and caspase-1 protein (Figures 6G-6L), in accordance with the findings of Hirota and colleagues (19), these proteins are not detected in ASM bundles in situ. Moreover, using protein homogenates from freshly isolated ASM strips of human tracheas from three donors, NLRP3 and caspase-1 were not detected by immunoblotting, as shown in Figure 6M. In contrast, a clear band for NLRP3 and caspase- 1 protein was evident in lysates from stimulated THP-1 macrophages, run in parallel as a positive control, whereas these proteins were expressed at lower concentrations in unstimulated cells. Collectively, our results demonstrate that NLRP3 and caspase- 1 are not expressed in ASM from human tracheal tissue.

\section{DISCUSSION}

Our data demonstrate that the Pam3CSK4-mediated augmentation of TNF- $\alpha$-induced IL- 6 and IL- 8 mRNA and protein concentrations is not mediated by IL-1 $\beta$ secretion via NLRP3 inflammasome activation in ASM cells. NLRP3 and caspase-1 are not detected immunohistochemically in situ, they are not present in dissected ASM strips from human tracheas, and these proteins are not expressed in ASM cells in vitro. Thus, the NLRP3 inflammasome is not activated in ASM upon TLR2 ligation.

Recent in vivo and in vitro studies have implicated the NLRP3 inflammasome as a potential therapeutic target in asthma (1-4), although debate continues $(22,23)$. To date, 


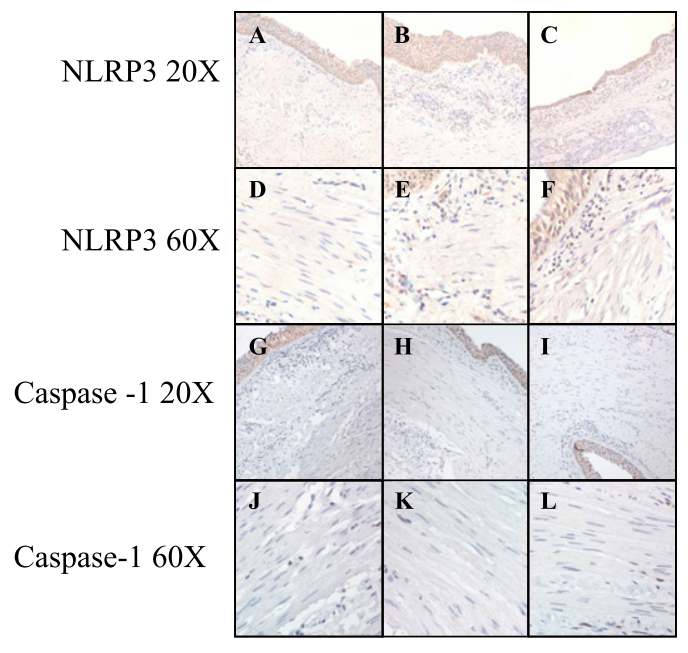

M

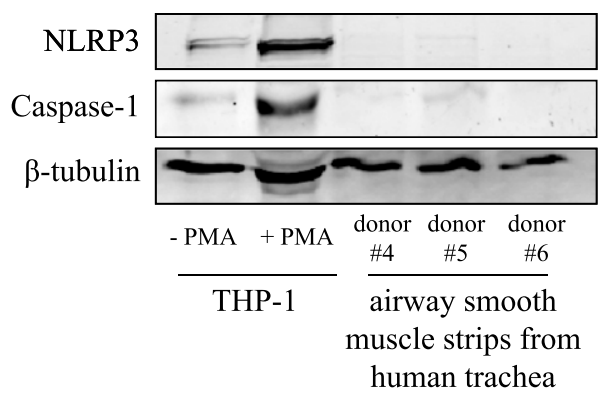

Figure 6. NLRP3 and caspase-1 are not expressed in human ASM from tracheal tissue. $(A-F)$ In situ immunohistochemistry of three human tracheas donated for medical research (see Table 1 for subject characteristics, i.e., Donors $1-3)$ for $(A-F)$ NLRP3 and $(G-L)$ caspase- 1 protein (brown $=$ positive stain) at $\times 20$ and $\times 60$ magnification. $(M)$ Immunoblots of NLRP3 and caspase- 1 in isolated airway smooth muscle strips from three human tracheas (see Table 1 for subject characteristics, i.e., Donors 4-6). Lysates from THP-1 monocytes treated without or with PMA $(50 \mathrm{ng} / \mathrm{ml})$ served as positive controls, and $\beta$-tubulin was used as a loading control.

several reports demonstrated the presence of the functional NLRP3 inflammasome in asthmatic airway epithelia (19, 24, $25)$. The NLRP3 inflammasome-mediated production of IL-1 $\beta$ in airway epithelial cells leads to airway neutrophilic inflammation (19), which is the predominant phenotype of airway inflammation in acute exacerbations $(26,27)$. Allen and colleagues in 2009 (24) demonstrated that the NLRP3 inflammasome expressed in airway epithelial cells and macrophages is required for inflammation after influenza infection. Thus, a growing body of research suggests that the NLRP3 inflammasome may be activated in the airways to promote increased cytokine expression and a proinflammatory milieu during infections.

Increasing evidence demonstrates that ASM cells play a role in the amplification of inflammatory responses during infectious exacerbations in asthma via augmented cytokine production $(18,28-31)$. Our study is the first to examine the involvement of the NLRP3 inflammasome and possible IL-1 $\beta$ secretion in Pam3CSK 4 and TNF- $\alpha$-induced cytokine up-regulation in ASM cells. Although Pam3CSK4 is primarily known as a TLR2 agonist, its ability to activate the NLRP3 inflammasome to release IL-1 $\beta$ has been demonstrated in macrophages (32). This led us to examine the effects of IL-1 $\beta$ neutralization on Pam 3 CSK 4 and TNF- $\alpha$-induced cytokine up-regulation. We first demonstrated that IL-1 $\beta$ induces a significant increase in
IL-6 and IL-8 protein secretion by ASM cells in a concentration-dependent manner. We also demonstrated that the IL-1 $\beta-$ induced up-regulation of IL- 6 and IL- 8 secretion is completely inhibited by IL-1 $\beta$-neutralizing antibody. These results show that the IL-1 $\beta$-neutralizing antibody can successfully neutralize the effects of IL-1 $\beta$ on cytokine up-regulation in ASM cells. However, the Pam3CSK4-induced up-regulation of IL-6 and IL-8 protein secretion was not inhibited by the neutralization of IL-1 $\beta$. This finding suggests that IL-1 $\beta$ secretion is not involved in TLR2 ligand-induced cytokine up-regulation in ASM cells.

In support of this, we also demonstrated that ASM cells treated with Pam3CSK 4 and TNF- $\alpha$ do not secrete detectable concentations of IL-1 $\beta$ protein over 24 hours, although gene expression is significantly augmented. For the NLRP3 inflammasome in ASM cells to be active in a classic manner, the production and secretion of mature IL-1 $\beta$ should be observed in response to Pam3CSK4 (33), because IL-1 $\beta$ secretion is widely accepted as a surrogate marker for NLRP3 inflammasome activation. However, TLR2 ligation by Pam3CSK4 appears unable to induce assembly of the NLRP3 inflammasome and the processing of IL-1 $\beta$ secretion. We were unable to detect the expression of NLRP3 and caspase-1 protein. Together, our results provide evidence that the NLRP3 inflammasome is not activated to promote IL-1 $\beta$ maturation and secretion in response to Pam 3 CSK 4 and TNF- $\alpha$ in ASM cells. This rules out the possibility that IL- $1 \beta$ secreted as a result of Pam3CSK4-enhanced, TNF- $\alpha$-induced IL- $1 \beta$ mRNA expression observed at an early time point $(4 \mathrm{~h})$ acts in an autocrine manner to boost the further augmentation of IL-6, IL-8, and IL$1 \beta$ gene expression at later time points $(24 \mathrm{~h})$ via a positive feedback loop.

The results presented here indicate important cell-type specificity in airway inflammation, because we demonstrate that the robust up-regulation of proinflammatory cytokines by invading pathogens may not be mediated by activation of the NLRP3 inflammasome and IL-1 $\beta$ secretion in ASM. Using primary cultures of human ASM cells, we demonstrated that Pam3CSK4 robustly up-regulates TNF- $\alpha$-induced IL-1 $\beta$ mRNA expression, but does not significantly change the expression of NLRP3 and caspase-1. Importantly, IL-1 $\beta$ is not secreted from ASM cells. Thus IL-1 $\beta$ is unable to act in an autocrine manner to induce an inflammatory milieu that mimics exacerbation in ASM cells by promoting IL-6 secretion and up-regulation of the neutrophil chemoattractant chemokine, IL-8. Moreover, although NLRP3 and caspase- 1 are present in human airway epithelium (corroborating Hirota and colleagues) (19), these proteins are not detected in the nearby ASM bundles in immunohistochemical analyses of human tracheas in situ.

Respiratory infections are key factors underlying asthma exacerbations. By propagating and amplifying inflammation in response to bacterial and viral pathogens, airway structural cells play an important immunomodulatory role in asthma. We explored the role of the NLRP3 inflammasome and the secretion of IL-1 $\beta$ from ASM cells in response to Pam3CSK4 activation, and although TLR2 ligation robustly enhanced cytokine expression, this up-regulation was IL-1 $\beta$-independent. Exacerbated asthmatic symptoms are not effectively attenuated by current pharmacological management. By addressing molecular mechanisms of exacerbation, our experiments have revealed a potentially important cell type difference, that is, whereas the NLRP3 inflammasome is activated in human airway epithelium (19), the TLR2-mediated enhancement of proinflammatory cytokine secretion in the underlying ASM layer is NLRP3 inflammasomeindependent. Although the functional relevance of the restricted localization of the NLRP3 inflammasome in the airways is unclear at present, crosstalk between airway structural cells (and 
inflammatory cells) remains a possibility. Thus, further studies are warranted to develop new therapeutic strategies to combat asthma exacerbations in the future.

Author disclosures are available with the text of this article at www.atsjournals.org.

Acknowledgments: The authors thank their colleagues in the Respiratory Research Group at the University of Sydney (Sydney, New South Wales, Australia). The authors also acknowledge the collaborative efforts of the cardiopulmonary transplant team and the pathologists at St. Vincent's Hospital (Sydney, New South Wales, Australia) and the thoracic physicians and pathologists at the Royal Prince Alfred Hospital, Concord Repatriation Hospital, Strathfield Private Hospital, and Rhodes Pathology (Sydney, Sydney, New South Wales, Australia). The authors also acknowledge the expert advice of Maria B. Sukkar (University of Technology, Sydney, New South Wales, Australia).

\section{References}

1. Birrell MA, Eltom S. The role of the NLRP3 inflammasome in the pathogenesis of airway disease. Pharmacol Ther 2011;130:364-370.

2. dos Santos G, Kutuzov MA, Ridge KM. The inflammasome in lung diseases. Am J Physiol Lung Cell Mol Physiol 2012;303:L627-L633.

3. Ather JL, Ckless K, Martin R, Foley KL, Suratt BT, Boyson JE, Fitzgerald KA, Flavell RA, Eisenbarth SC, Poynter ME. Serum amyloid A activates the NLRP3 inflammasome and promotes Th17 allergic asthma in mice. J Immunol 2011;187:64-73.

4. Besnard AG, Guillou N, Tschopp J, Erard F, Couillin I, Iwakura Y, Quesniaux V, Ryffel B, Togbe D. NLRP3 inflammasome is required in murine asthma in the absence of aluminum adjuvant. Allergy 2011;66: 1047-1057.

5. Bauer RN, Brighton LE, Mueller L, Xiang Z, Rager JE, Fry RC, Peden DB, Jaspers I. Influenza enhances caspase-1 in bronchial epithelial cells from asthmatic volunteers and is associated with pathogenesis. J Allergy Clin Immunol 2012;130:958-967.

6. Bochkov YA, Hanson KM, Keles S, Brockman-Schneider RA, Jarjour NN, Gern JE. Rhinovirus-induced modulation of gene expression in bronchial epithelial cells from subjects with asthma. Mucosal Immunol 2010;3:69-80.

7. Cassel SL, Joly S, Sutterwala FS. The NLRP3 inflammasome: a sensor of immune danger signals. Semin Immunol 2009;21:194-198.

8. Schroder K, Tschopp J. The inflammasomes. Cell 2010;140:821-832.

9. Bauernfeind FG, Horvath G, Stutz A, Alnemri ES, MacDonald K, Speert D, Fernandes-Alnemri T, Wu J, Monks BG, Fitzgerald KA, et al. Cutting edge: NF-kappaB activating pattern recognition and cytokine receptors license NLRP3 inflammasome activation by regulating NLRP3 expression. J Immunol 2009;183:787-791.

10. Qiao Y, Wang P, Qi J, Zhang L, Gao C. TLR-induced NF-kappaB activation regulates NLRP3 expression in murine macrophages. FEBS Lett 2012;586:1022-1026.

11. Damera G, Tliba O, Panettieri RA Jr. Airway smooth muscle as an immunomodulatory cell. Pulm Pharmacol Ther 2009;22:353-359.

12. Ozier A, Allard B, Bara I, Girodet PO, Trian T, Marthan R, Berger P. The pivotal role of airway smooth muscle in asthma pathophysiology. $J$ Allergy (Cairo) (In press).

13. Hedges JC, Singer CA, Gerthoffer WT. Mitogen-activated protein kinases regulate cytokine gene expression in human airway myocytes. Am J Respir Cell Mol Biol 2000;23:86-94.

14. Henness S, Johnson CK, Ge Q, Armour CL, Hughes JM, Ammit AJ. Il17A augments TNF-alpha-induced IL-6 expression in airway smooth muscle by enhancing mRNA stability. J Allergy Clin Immunol 2004; 114:958-964.

15. Laporte JD, Moore PE, Panettieri RA, Moeller W, Heyder J, Shore SA. Prostanoids mediate IL-1beta-induced beta-adrenergic hyporesponsiveness in human airway smooth muscle cells. Am J Physiol 1998;275:L491-L501.

16. Liang $\mathrm{KC}$, Lee $\mathrm{CW}$, Lin $\mathrm{WN}$, Lin $\mathrm{CC}, \mathrm{Wu} \mathrm{CB}$, Luo SF, Yang CM. Interleukin-1beta induces MMP-9 expression via p42/p44 MAPK, p38 MAPK, JNK, and nuclear factor-kappaB signaling pathways in human tracheal smooth muscle cells. J Cell Physiol 2007;211:759_ 770 .

17. Damera G, Panettieri RA Jr. Does airway smooth muscle express an inflammatory phenotype in asthma? Br J Pharmacol 2011;163:6880.

18. Manetsch M, Seidel P, Heintz U, Che W, Hughes JM, Ge Q, Sukkar MB, Ammit AJ. TLR2 ligand engagement upregulates airway smooth muscle TNFalpha-induced cytokine production. Am J Physiol Lung Cell Mol Physiol 2012;302:L838-L845.

19. Hirota JA, Hirota SA, Warner SM, Stefanowicz D, Shaheen F, Beck PL, Macdonald JA, Hackett TL, Sin DD, Van Eeden S, et al. The airway epithelium nucleotide-binding domain and leucine-rich repeat protein 3 inflammasome is activated by urban particulate matter. $J$ Allergy Clin Immunol 2012;129:1116-1125.

20. Johnson PR, McKay KO, Armour CL, Black JL. The maintenance of functional activity in human isolated bronchus after cryopreservation. Pulm Pharmacol 1995;8:43-47.

21. Rajan JV, Warren SE, Miao EA, Aderem A. Activation of the NLRP3 inflammasome by intracellular poly I:C. FEBS Lett 2010;584:46274632.

22. Kool M, Willart MA, van Nimwegen M, Bergen I, Pouliot P, Virchow JC, Rogers N, Osorio F, Reis e Sousa C, Hammad H, et al. An unexpected role for uric acid as an inducer of $\mathrm{T}$ helper 2 cell immunity to inhaled antigens and inflammatory mediator of allergic asthma. Immunity 2011;34:527-540.

23. Allen IC, Jania CM, Wilson JE, Tekeppe EM, Hua X, Brickey WJ, Kwan M, Koller BH, Tilley SL, Ting JP. Analysis of NLRP3 in the development of allergic airway disease in mice. J Immunol 2012;188: 2884-2893.

24. Allen IC, Scull MA, Moore CB, Holl EK, McElvania-TeKippe E, Taxman DJ, Guthrie EH, Pickles RJ, Ting JP. The NLRP3 inflammasome mediates in vivo innate immunity to influenza A virus through recognition of viral RNA. Immunity 2009;30:556-565.

25. Tran HB, Lewis MD, Tan LW, Lester SE, Baker LM, Ng J, Hamilton-Bruce MA, Hill CL, Koblar SA, Rischmueller M, et al. Immunolocalization of NLRP3 inflammasome in normal murine airway epithelium and changes following induction of ovalbumin-induced airway inflammation. J Allergy (Cairo) (In press).

26. Cowan DC, Cowan JO, Palmay R, Williamson A, Taylor DR. Effects of steroid therapy on inflammatory cell subtypes in asthma. Thorax 2010; 65:384-390.

27. ten Brinke A, Zwinderman AH, Sterk PJ, Rabe KF, Bel EH. "Refractory" eosinophilic airway inflammation in severe asthma: effect of parenteral corticosteroids. Am J Respir Crit Care Med 2004;170: 601-605.

28. Elias JA, Wu Y, Zheng T, Panettieri R. Cytokine- and virus-stimulated airway smooth cells produce IL-11 and other IL-6-type cytokines. Am J Physiol Lung Cell Mol Physiol 1997;273:L648-L655.

29. Morris GE, Parker LC, Ward JR, Jones EC, Whyte MK, Brightling CE, Bradding P, Dower SK, Sabroe I. Cooperative molecular and cellular networks regulate Toll-like receptor-dependent inflammatory responses. FASEB J 2006;20:2153-2155.

30. Oliver BG, Johnston SL, Baraket M, Burgess JK, King NJ, Roth M, Lim $\mathrm{S}$, Black JL. Increased proinflammatory responses from asthmatic human airway smooth muscle cells in response to rhinovirus infection. Respir Res 2006;7:71.

31. Sukkar MB, Xie S, Khorasani NM, Kon OM, Stanbridge R, Issa R, Chung KF. Toll-like receptor 2, 3, and 4 expression and function in human airway smooth muscle. J Allergy Clin Immunol 2006;118:641648.

32. Kanneganti TD, Ozoren N, Body-Malapel M, Amer A, Park JH, Franchi L, Whitfield J, Barchet W, Colonna M, Vandenabeele P, et al. Bacterial RNA and small antiviral compounds activate caspase-1 through cryopyrin/NALP3. Nature 2006;440:233-236.

33. Martinon F, Mayor A, Tschopp J. The inflammasomes: guardians of the body. Annu Rev Immunol 2009;27:229-265. 
Reproduced with permission of the copyright owner. Further reproduction prohibited without permission. 